\title{
Employee Turnover in a Local Government Department
}

\author{
C. Pietersen \\ Department of Business Management, \\ University of Limpopo, Turfloop Campus 0727, Republic of South Africa \\ charlotte.pietersen@ul.ac.za \\ O. A. Oni \\ Department of Business Management, \\ University of Limpopo, Turfloop Campus 0727, Republic of South Africa \\ olabanji.oni@ul.ac.za
}

\section{Doi:10.5901/mjss.2014.v5n2p141}

\section{Abstract}

This study explored employee turnover in a local government department in Limpopo Province, South Africa. A cross-sectional mixed method design (questionnaires, key informant interview, focus group and document analysis) was used to collect employee turnover data from a stratified sample of participants as well as key role players in the department under investigation. The results of the study show a high overall employee turnover rate and high turnover among younger employees, females and employees in specific job categories. Job dissatisfaction in the department is attributed to poor compensation and better job offers elsewhere, inferior working conditions, and a lack of promotional opportunities. Low job satisfaction is attributed to problematic interpersonal relationships and the autocratic management style of supervisors. The findings of the study provide evidence of the most pressing turnover problems that a government department in a less affluent geographic region experiences. The impact of job satisfaction and job dissatisfaction on the productivity, efficiency and service delivery of a government department is highlighted. A number of human resource practices are recommended to manage employee retention in the department.

Keywords: Employee turnover rates; employee turnover drivers; engagement/involvement; turnover costs; retention practices

\section{Introduction}

In recent years an unprecedented wave of service delivery protests has flooded South Africa. It would appear that South African citizens continue to lose confidence in the efficiency and productivity of government departments. Powell (2009) has noted that local governments are the least trusted of all public institutions in the country. In order for South Africa to realize its service delivery mandate, a stable and reliable staff compliment with the necessary competencies, is vital (Sing, 2012). A key factor that undermines the business performance of public sector organizations and also local government departments is high employee turnover (Meier \& Hicklin, 2008; Tariq, Ramzan \& Riaz, 2013). It is therefore crucial to monitor labour turnover and to determine why turnover takes place to ensure that sufficient skills are available to meet the business objectives of local government departments (Pillay, 2011).

Employee turnover also pose serious challenge to service delivery and economic growth in Limpopo Province, South Africa. Research findings have indicated that perceived alternative employment is a major cause of employee turnover in the public sector (Ikwukananne, 2009). This finding appears to be applicable to government departments in Limpopo Province as well. The province is a largely rural province and has to compete for human resource capacity with more well-to-do and established metropolitan areas in other provinces (Radebe, 2009). The reduction of dysfunctional employee turnover is one of the most effective ways to decrease staff shortages (Evans, 2005; Lacey, 2003) and to enhance the business performance of local government departments (Bertelli, 2007). Therefore, local government departments in the Limpopo Province have to implement effective employee retention strategies to discourage dysfunctional employee turnover.

Although a considerable amount of research has been conducted on employee turnover and the causes of employee turnover in developed countries, less attention has been paid to this issue in developing countries (Shahzad, Hayat, Abbas \& Bashir, 2011). The aim of the present study is to explore employee turnover in a local government 
department in Limpopo Province. The objectives of the study are to:

- Determine the extent to which employee turnover rates are problematic in the department;

- Identify turnover drivers in the department;

- Highlight reasons for managing employee turnover;

- Recommend retention practices to the department.

\section{Literature Review}

\subsection{Employee turnover and employee turnover rates}

Employee turnover is a generic term that refers to movement employees from one work organization to another (Allen, 2008; Choi, Musibau, Khalil \& Ebi, 2012). It can be initiated by an employee (voluntary turnover) or by an employer (involuntary turnover). Involuntary turnover can also be attributed to uncontrollable factors such as death, retirement or ill health. Yearly surveys conducted by the Chartered Institute of Personnel and Development (CIPD) have shown consistently that the majority of employee turnover is attributed to voluntary turnover (CIPD, 2011). Voluntary turnover is a major concern for organizations when it is dysfunctional (Champion, 1991).

Lynch and Tuckey (2008:8) recommend an inspection of the employee turnover profile of an organization to help the organization to recognize particular demographic groups and turnover hotspots within the organisation that warrant attention. This, in turn, could guide the development of appropriate interventions to minimize turnover. The turnover profile could be established by calculating employee turnover rates in an organization. It is possible to break the overall turnover rate down into subcategories to compare turnover rates between employees on different organizational levels and for different age and gender groups within an organization.

\subsection{Job satisfaction and job dissatisfaction}

Contemporary Human Resource Management is defined as '...the productive use of people in achieving the organisation's strategic objectives and the satisfaction of individual employee needs' (Stone, 2005:4). The need fulfilment model proposes that one's experience of satisfaction or dissatisfaction will often be a function of the extent to which one perceives that one's needs are being met (Kasimati, 2011). Masri (2009) observed that an understanding of the needs of employees is essential to ensure their satisfaction and to reduce employee turnover.

Job satisfaction has emerged as the most widely studied predictor of turnover (Liu, Mitchell, Lee, Holtom \& Hinkin, 2012). However, research findings on the job satisfaction of public sector employees are contradictory. Some researchers found overall job satisfaction to be high among public employees at all levels of government, whereas other studies reached an opposite conclusion (Bright 2008; Kasimati, 2011).

A well quoted definition of job satisfaction is that it is 'a positive or pleasurable affective response resulting from the appraisal of various facets of one's job or job experiences' (Kasimati, 2011: 321). However, low job satisfaction alone is not enough to account for turnover. One also has to take job dissatisfaction that is related to the satisfaction of extrinsic job needs into account. Research findings indicate that both job satisfaction and job dissatisfaction lead to employee turnover (Griffith, Horn, \& Gaertner, 2000; Poulin; 1994; Shahzad, et al., 2011; Yücel, 2012).

Herzberg's motivation-hygiene theory explains the difference between the two concepts. He distinguishes between two sets of factors (motivators and hygiene factors) that act independently of each other (Herzberg, Mausner \& Snyderman, 1959). Intrinsic motivators (nature of the work itself, recognition, autonomy, sense of achievement and personal growth and advancement) lead to satisfaction. They gratify needs such as needs for achievement, competency, status, personal worth and self-realization.

However, the absence of motivators does not lead to unhappiness and dissatisfaction. Instead, dissatisfaction results from an unfavourable assessment of 'hygiene factors'. Hygiene factors (compensation, job security, working conditions, company policies and administration, supervision, and interpersonal relations) are extrinsic to a job itself and lead to dissatisfaction if workers have negative affective responses to them (Hertzberg, 1968).

\subsection{Employee turnover drivers}

Allen (2008) uses the term 'drivers' to refer to factors that cause employee turnover. The work of Porter and Steers (1973) provide a useful framework to categorize employee turnover drivers. They use the concept of 'met expectations' 
to explain turnover. Long, Ajagbe, Nor and Suleiman (2012: 284) describe the concept as a discrepancy between what a person encounters on a job in the form of positive and negative experiences and what he or she expects to encounter. $A$ person's inclination to withdraw from a work situation will increase when his or her expectations are not being met. Porter and Steers compiled an 'expectation set' that is used in the present study to categorize turnover drivers into four groups personal, organization-wide, work-environmental and job-related drivers.

\subsubsection{Personal turnover drivers}

A review of research findings show that older employees who have been in a position longer are less inclined to resign compared to younger employees (Grissom, Nicholson-Crotty \& Keiser, 2012; Kabungaidze, Mahlatshana \& Ngirande, 2013).

In addition, the turnover rates for females is higher compared to men and this tendency could largely be attributed to the family and child care responsibilities of female employees (Cotton \& Tuttel, 1986). High female turnover is also attributed to a lack of career advancement while male employees leave because of a lack of proper organizational objectives and promotional opportunities (Nel, Van Dyk, Haasbroek, Schultz, Sono \& Werner, 2011). However, although women traditionally were significantly more likely to quit than their male counterparts, more recent research findings indicate that women are now less likely to leave public organizations than men. Changes in labour force participation partially explain these findings (Moynihan \& Landuyt, 2008).

Moreover, Nel, Erasmus and Swanepoel (2001) attribute employee turnover the job position of an individual in an organization. Research findings suggest that employees in lower job categories find their jobs less financially and/or psychologically rewarding (Kellough \& Haoran, 1993).

\subsubsection{Organization-wide turnover drivers}

Organization wide turnover drivers include the following hygiene factors: development/training and promotion policies, compensation, working conditions and job security. Surveys of previous research suggests that poor human resource policies, lack of career advancement opportunities and poor compensation packages (pay and benefits) are negatively associated with employee turnover (Grissom, et al., 2012; Ito, 2003). Compensation, working conditions and development opportunities were found contribute most to the job dissatisfaction and turnover of public service employees (Kasimati, 2011; Meier \& Hicklin, 2008; Miceli \& Mulve, 2000; Singh \& Loncar, 2012; Sulaiman \& Ogunsina; 2011). Job insecurity could also lead to turnover when better opportunities are offered by other employers (Walsh \& Taylor, 2007).

\subsubsection{Work-environment turnover drivers}

These drivers include the following hygiene factors: supervisor and co-worker relations. Relationships with co-workers and the behaviour and management style of supervisors play an important role in the job dissatisfaction and turnover of public sector employees (Bertelli, 2007; Kasimati, 2011; Seymour \& Buscherhof, 1991; Sulaiman \& Ogunsina; 2011).

\subsubsection{Job-related turnover drivers}

Job related drivers include intrinsic motivators such as the nature of job requirements, autonomy, challenging work and a sense of achievement, as well as job stress and feedback. Employees will leave when better growth opportunities and a challenging job are offered by other employers (Walsh \& Taylor, 2007). Autonomy and stress are also of particular importance in the job satisfaction and turnover of public employees (Kasimati, 2011; Sulaiman \& Ogunsina; 2011).

It is evident that both job satisfaction and dissatisfaction are important determinants of employee turnover. It could be argued that employees in Limpopo Province would not seek employment elsewhere in greater metropolitan areas in South Africa if their job needs and expectations can be met within the province.

\subsection{Reasons for managing employee turnover}

Turnover has to be management because it is costly and because it affects business performance (Allen, 2008: 3). Employee turnover can incur both direct and indirect costs (Van der Merwe \& Miller, 1988). 


\subsubsection{Direct costs}

When an employee leaves, an organization is forced to spend financial and other resources to replace the leaver (Abbasi \& Hollman, 2000; Griffith \& Horn, 2001; Singh \& Longcar, 2010). Financial costs include separation costs and replacement costs such as recruitment, selection, hiring and training expenses. From a utilitarian perspective it is argued that the satisfaction or dissatisfaction of employees can lead to behaviours that affect the functioning of the organization. It is associated with high levels of voluntary turnover which can in turn reduce the productivity, efficiency and service delivery in government departments (Chen, 2008; Spector 1997; Waldman, Kelly, Arora \& Smith, 2004; Wright \& Kim, 2004). Voluntary employee turnover has a more significant and negative impact on organizational performance and effectiveness than involuntary turnover (Shaw, Gupta, \& Delery, 2005; Tariq, et al., 2013). A lower turnover rate could reduce separation and replacement costs and increase employees' loyalty and commitment to an organization which in turn could lead to better organizational performance.

\subsubsection{Indirect costs}

Indirect costs of employee turnover include disrupted organizational processes, low morale, adjustment time of replacement employees, a poor organizational image, customer dissatisfaction, and most importantly, a loss of human capital (Grissom, et al., 2012; Rainey 2003; Sing \& Loncar, 2010; Wang, et al., 2012). A loss of human capital is of particular importance in Limpopo Province because the region can ill afford lose it human resource assets to other provinces.

\subsection{Retention practices to reduce dysfunctional employee turnover}

According to Liu, et al. (2012), organizations should endeavour to promote and reinforce retention strategies that lead to positive changes in employee job satisfaction and minimize dissatisfaction in order to maintain their valuable human resources. Various retention strategies can be used to address the employee turnover rates in organizations (Steel, et al., 2002). Research findings cited by Allen (2008: 15) show that the top ten retention initiatives used are market adjustment/base salary increase; hiring bonus; work environment (e.g., flexible schedules, casual dress, telecommuting); retention bonus; promotion and career development opportunities; above-market pay; special training and educational opportunities; individual spot bonuses; stock programs; and project milestone/completion bonuses.

External causes of employee turnover, such as supply and demand in the labour market and job alternatives cannot be controlled by an organization. If dysfunctional employee turnover cannot be prevented then organizations have to plan proactively to minimize the effects of turnover in the future. The causes of involuntary turnover are also outside the control of an organization but the costs that such turnover imposes on the organization should be managed. One possibility is to redesign jobs or processes to lower the transaction costs associated with involuntary turnover (Meier \& Hicklin, 2008).

On the other hand, research findings cited by Allen (2008) provide evidence that the internal drivers of voluntary employee turnover can be managed through the use of a number of human resource practices. Human resource theories have emphasized the importance of increasing power, information, rewards, and knowledge (PIRK) for employees as a tool to enhance organizational effectiveness and lower employee turnover (Haines, Jalette \& Larose, 2010; Vandenberg, Richardson \& Eastman, 1999). An increase in PIRK will increase worker involvement and worker engagement by increasing job satisfaction and decreasing job dissatisfaction. Research findings support the argument that highinvolvement practices are likely to lower turnover rates (Guthrie, 2001). Turnover can be reduced by increasing employee engagement because engaged workers believe that their employer values their contributions, that their work is important, they enjoy their work, they take pride in their organization and they are satisfied with their jobs (Allen, 2008).

A number of human resource practices can be employed to increase job satisfaction and decrease job dissatisfaction. These include staffing, training and development, compensation and supervision (Allen, 2008). An organisation should develop a well-informed retention policy (Kim, 2012) that is aligned with other human resource policies and an organization's business objectives.

\subsubsection{Staffing}

Job design/redesign can be used to change the job range (through job enrichment and job rotation) and job depth to 
increase task significance, autonomy, task identity and task variety of an employee's job (Nel, et al., 2011; Wang, et al., 2012). This will help to strengthen job engagement and to increase job satisfaction (Allen, 2008). Additionally, job engagement will increase when an internal recruitment strategy is used to promote employees from within an organization (Allen, 2008). Organizations that allow greater internal opportunities for advancement are more successful at retaining employees (Nel, et al., 2011). By letting employees know that a variety of career paths are available to them, state government agencies can reduce feelings of neglect that often lead to increased turnover (Kim, 2012). Transparent and fair policies and procedures for development and advancement would also motivate females and other previously disadvantages groups to make use of the opportunities available to them.

It is important not to lower selection standards in high turnover situations and to ensure that selection is vacancy specific (Van der Merwe \& Miller, 1993). During the selection process clear communication should be used to establish a person-job and a person-organization fit (Allen, 2008). Biographical data used for selection purposes could provide an indication of, for example, tenure in previous jobs and are predictive of retention (Griffith \& Horn, 2001).

Research evidence suggests that proper induction (and re-induction) is related to increased tenure in an organization (Kammeyer-Mueller \& Wanberg, 2003) and help new employees become embedded in their new work organization (Allen, 2006). Presenting applicants with a realistic job preview (RJP) has a positive effect on retention of new (and redeployed) employees (Breaugh \& Starke, 2000; Nel, et al., 2011). Job engagement will be increased by reducing the discrepancy between employee expectations and reality which in turn could reduce actual turnover (Hom, Griffeth \& Sellaro, 1984). Job engagement will also be increased by demonstrating to new and current employees how their jobs contribute to the organization's mission (Allen, 2008). Job involvement will be increased by letting employees see the fit between their personal goals and organizational goals (Sherman \& Bohlander, 1992; Sing, 2012).

\subsubsection{Training and development}

Access to opportunities for ongoing training and the development of managerial competencies and skills can be used to increase job engagement and to reduce job dissatisfaction. Allen, Shore and Griffeth (2003) as well as Rhoades and Eisenberger (2002) found that human resource practices that promote growth opportunities simultaneously lower employee turnover. Such programs reduce turnover by removing skill-related obstructions (Sherman \& Bohlander, 1992; Sing, 2012).

However, training and development opportunities may actually increase turnover by increasing employees' external marketability and ease of movement (Haines, et al., 2010). Allen (2008) recommends that in order to retain employees, job-specific training instead of more general and transferable training that will make an employee more attractive to other organization should be provided. Fortunately government departments typically require more specific skill sets.

\subsubsection{Compensation}

Job engagement can be increased by providing positive feedback and recognition for all types of contributions by employees (Allen, 2008) and in particular for value-adding contributions (Nel, et.al, 2011). Allen, et al. (2003) found that human resource practices that increase the availability of fair rewards lower employee turnover intentions. Research findings (Rhoades \& Eisenberger) show that rewards are strongly related to organizational support perceptions which are related to turnover intentions. Competitive and fair compensation packages are crucial to decrease dissatisfaction and to minimize the attractiveness of alternative employment. Research findings have consistently indicated that high pay and generous benefit packages reduce turnover rates (Haines, et al., 2010). Well-designed employee benefit packages, onsite childcare and family-friendly programs are effective tools for retaining government employees (Kim, 2012). However, compensation poses a particular challenge for public sector organizations. They must compete to retain workers with compensation packages that are often lower than those offered by private sector competitors (Ingraham, Selden \& Moynihan, 2000).

Variable pay (e.g., skill-based pay, pay-for-competencies, individual incentives, profit sharing and share ownership plans) can be considered as an alternative to traditional pay systems. Variable pay reduces turnover because an organization that make use of flexible pay systems can respond to alternative compensation offers (Azfar \& Danninger 2001; Blakemore, Low \& Ormiston 1987).

Performance based pay has been suggested as another alternative to traditional pay systems used in bureaucratic government organizations. Pay-for-performance is used for senior managers in local government 
departments (Republic of South Africa, 2001) but not for lower level employees. However, the use of pay-forperformance should be considered with care. Some studies found that this pay scheme do not improve motivation or increase employee satisfaction (Kellough \& Lu 1993). Sturman, Boudreau and Gerhart (2003) found that it may increase retention among high performers but increases turnover among low performers. One possible reason for this is that performance-based pay fosters financial uncertainty among lower level employees (Batt, Colvin \& Keefe, 2002).

\subsubsection{Supervision}

Improvement of the quality of supervision could play a key role in the reduction job dissatisfaction and employee turnover. If turnover is high in a supervisor's department then he or she requires assistance. Coaching and training should be used to develop the planning, organizing, directing and controlling skills of supervisors (Allen, 2008) as well as their leadership skills. Supervisors should be motivated to use a people-orientated leadership style instead of being autocratic in their interactions with their subordinates to build morale and to reduce turnover. An autocratic leadership style is characterized by poor communication between supervisors and subordinates.

Conversely, when employees perceive that they are supported and cared for, they are likely to stay with the employer as a form of reciprocation (Eisenberger, Rexwinkel, Lynch, \& Rhodes, 2001). According to Grobler, Wärnich, Carrell, Elbert and Hatfield (2006), unions in South Africa insist that supervisors treat their subordinates fairly, justly and with respect. Supervisors should be supportive and allow subordinates to voice their concerns. They should also provide constructive and informative performance feedback and evaluations and facilitate employee skills development (Kim, 2012; London \& Larson, 1999). Any grievances or disciplinary resolution procedures should improve employees' perceptions of both procedural and distributive justice (Haines, et al., 2010). As a linking pin between management and workers supervisors not only communicate policies and instructions from management to workers. Vandenberg et al. (1999) found that providing employees with access to information about the organization is negatively related to turnover intentions. Supervisors can also show support and care for their subordinates by making management aware of worker problems that could lead to turnover.

However, proper supervision alone will not improve employee retention. Supervisors have to manage physical working conditions (e.g., availability of facilities, equipment and appliances, healthy, safe and hygiene conditions) as well as psychological working conditions (e.g., effects of work pressure as a result of work overload or work underload, working hours and unmet expectations) in their departments to decrease job dissatisfaction (Nel, et al, 2011; Shahzad et al., 2011).

\section{Method}

\subsection{Population and Samples}

A cross-sectional mixed method design (questionnaires, interview, focus group and document analysis) was used to collect employee turnover data from the target population in a relative short period of time. Only one local government department in Limpopo Province was willing to participate in the study. This department has a staff complement of 1081 employees.

The questionnaire was distributed among a sample of 60 employees. It was decided to select minimum sample size of $5 \%$ for this survey because of time and financial constraints. Stratified sampling was used to obtain a greater degree of representation (decreasing the sampling error). The human resource manager (identified as a key informant) of the department was interviewed. Eight employees (two from each of the four organizational levels), including a representative from the workers committee, participated in the focus group.

Before conducting the research, employees were informed that their identity would be kept confidential and the information obtained would be used for research purposes only and that only grouped data will be reported. The department's contact person insisted that in order to maintain confidentiality of information the name of the department and any other identifying information must not be divulged.

\subsection{Instrumentation}

A semi-structured, custom-made questionnaire was administered to the participants. They had to indicate their gender and job position in the department. Open-ended and close-ended items were used to identify the causes and 
consequences of turnover. Participants were asked to rate employee turnover over the past three years on a four-point Likert-type response scale, varying from very high $(v a l u e=1)$ to very low (value $=4)$. They also had to express their opinions about the impact of turnover (very high; high; low; very low) in the department.

The Chief Information Officer of the department sent a memo to all employees in the department to inform them of the purpose of the study. Questionnaires were distributed by hand. In order to prevent a poor return rate and to answer any queries about questionnaire items, a researcher was available during questionnaire completion. Questionnaires were collected immediately after they had been completed.

The human resource manager of the department was interviewed on the causes of turnover from a managerial perspective. A semi-structured interview format was used.

The hour-long focus group discussion focused on the drivers of employee turnover. A focus group interview was used because it is a valuable source of information to highlight the reasons why employees leave an organization (Allen, 2008; 17).

Data on employee turnover rates and the financial costs to replace employees was collected from the department's annual report from the previous year. Archival data was used because the study was conducted in April and statistics on the movement of employees were not available for the whole year.

\subsection{Data analysis}

A combination of statistical and non-statistical techniques was used to analyse data. Data obtained from different methods and segments of the sampled population were combined to identify patterns of convergence and divergence in the data. Quantitative data was processed using the Statistical Package for Social Sciences (SPSS v. 18.0). Descriptive statistics (frequency, average and percentage) were calculated.

The method used to calculate the employee turnover rates was developed by the CIPD (The Chartered Institute of Personnel and Development, 2004:2). Employee turnover rates were calculated by determining the ratio of the total number of leavers over the previous year to the average total number employed over the same period multiplied by 100. The total turnover rate and turnover rates based on position, gender and age groupings were calculated. Both voluntary and involuntary employee turnover were considered in the calculations.

Both the interview and focus group discussion were audio-taped, transcribed and stored electronically. The protocols were read, segmented, listed and numbered. Open-ended questionnaire items were also segmented, listed and numbered. The segments were then categorized. Close-end questionnaire responses were coded without any additional segmentation of the content. All the data obtained were then summarized to inform the objectives of the study.

\section{Findings}

\subsection{Sample composition}

The majority of subjects (67\%) are operative employees and the gender distribution is equal (Table 1).

Table 1. Stratified Sample Size based on Position and Gender

\begin{tabular}{|l|c|c|c|c|}
\hline \multicolumn{1}{|c|}{ Positions } & $\begin{array}{c}\text { Population } \\
\text { frequency }\end{array}$ & $\begin{array}{c}\text { Percentage } \\
\text { required }\end{array}$ & $\begin{array}{c}\text { Respondents } \\
\text { frequency }\end{array}$ & $\begin{array}{c}\text { Proportion of } \\
\text { males to females }\end{array}$ \\
\hline Top and senior management & 13 & $1 \%$ & 2 & $1: 1$ \\
\hline Middle management & 90 & $8 \%$ & 4 & $2: 2$ \\
\hline Lower management & 254 & $23 \%$ & 14 & $7: 7$ \\
\hline Operative employees & 724 & $67 \%$ & 40 & $20: 20$ \\
\hline Total & 1081 & $100 \%$ & 60 & $30: 30$ \\
\hline
\end{tabular}

\subsection{Employee turnover rates}

Table 2 shows the following with regard to the employee turnover rate in the previous year:

- The employee turnover rate for the previous year is $23.59 \%$.

- The turnover rate based on various categories of employees show that the turnover rate is highest among operatives (26.48\%). The turnover rate in the lower management level is also high (21.97\%). An inspection of 
Table 1 and Table 2 also show that, although the total number of employees remained unchanged, a shift in the number of employees on the lower management and operative level from the one year to the next year has taken place.

- The employee turnover rate based on age group indicates a higher turnover rate among younger employees (24.41\%) compared to older employees (18.18\%).

- The female employee turnover rate is very high (42.59\%) compared to the male employee turnover rate of $10.94 \%$.

Table 2. Employee Turnover Rate based on Position, Age Group and Gender

\begin{tabular}{|l|l|c|c|c|}
\hline \multicolumn{1}{|c|}{ Particulars } & \multicolumn{1}{|c|}{ Variables } & Frequency & Terminations & Turnover rates (\%) \\
\hline \multirow{4}{*}{ Positions } & Top and senior management & 13 & 0 & 0.00 \\
& Middle management & 90 & 12 & 13.33 \\
& Lower management & 335 & 78 & 21.97 \\
& Operative employees & 623 & 165 & 26.48 \\
\hline \multirow{2}{*}{ Age groups } & $20-39$ & 938 & 229 & 24.41 \\
& $40-$ over 69 & 143 & 26 & 18.18 \\
\hline \multirow{2}{*}{ Gender } & Male & 649 & 71 & 10.94 \\
\hline Total per variable & Female & 432 & 184 & 42.59 \\
\hline
\end{tabular}

The ratings of the respondents who complete the questionnaire show the majority (81.7\%) of the sample perceived that turnover rate over the past three years to be very high to high (Table 3).

Table 3: Perceived Turnover Rate over a Three Year Period

\begin{tabular}{|c|c|c|}
\hline Rankings & Frequency & Percentage of respondents \\
\hline Very high/high & 49 & $81.6 \%$ \\
\hline Low/very low & 11 & $18.3 \%$ \\
\hline Total & 60 & $100.0 \%$ \\
\hline
\end{tabular}

\subsection{Causes of employee turnover}

The findings in Table 2 show that position, age and gender impact on employee turnover in the department. The questionnaire, focus group and key informant interview results highlighted other major factors that cause employee turnover.

Table 4. Drivers of Employee Turnover

\begin{tabular}{|c|c|c|c|}
\hline Data source & Type of turnover & Causes & Drivers \\
\hline Interview & $\begin{array}{l}\text { Voluntary } \\
\text { Involuntary }\end{array}$ & $\begin{array}{l}\text { External } \\
\text { Internal }\end{array}$ & $\begin{array}{l}\text { Better job offers elsewhere } \\
\text { Rigid departmental human recourse management policies } \\
\text { Deaths } \\
\text { Dismissals } \\
\text { Retirement }\end{array}$ \\
\hline Focus group & Voluntary & $\begin{array}{l}\text { External } \\
\text { Internal }\end{array}$ & $\begin{array}{l}\text { Better job offers elsewhere } \\
\text { Poor compensation } \\
\text { Poor working conditions } \\
\text { Lack of promotion opportunities } \\
\text { Poor interpersonal relationships } \\
\text { Autocratic supervisor management style }\end{array}$ \\
\hline Questionnaire & Voluntary & $\begin{array}{l}\text { External } \\
\text { Internal }\end{array}$ & $\begin{array}{l}\text { Better job offers elsewhere } \\
\text { Poor compensation } \\
\text { Poor working conditions } \\
\text { Lack of promotion opportunities } \\
\text { Poor interpersonal relationships } \\
\text { Autocratic supervisor management style }\end{array}$ \\
\hline
\end{tabular}


The following is evident from Table 4:

- From a human resource management perspective, the department lose employees as a result of both voluntary and involuntary employee turnover. However, neither the focus group and nor questionnaire respondents identified involuntary turnover as a problem in the department.

- There is consensus among all three data sources that only one external factor (better job offers elsewhere) contributes to voluntary employee turnover in the department.

- The human resource manager identified rigid departmental human resource management policies as an internal driver that contributes to voluntary employee turnover.

- Both the focus group and the questionnaire respondents identified five internal drivers that contribute to voluntary employee turnover.

\subsection{Consequences of employee turnover}

On the average it costs R447 000 to recruit a top manager, R273 000 to recruit a middle manager, R209 000 to recruit a lower manager and R 192000 to recruit an operative employee (Table 5).

Table 5: Employee replacement costs

\begin{tabular}{|l|c|}
\hline \multicolumn{1}{|c|}{ Positions } & Average personnel cost \\
\hline Top \& senior management & R447 000 \\
\hline Middle management & R273 000 \\
\hline Lower management & R209 000 \\
\hline Operative employees & R192 000 \\
\hline Total & R1121 000 \\
\hline
\end{tabular}

The majority of respondents who complete the questionnaire (81.7\%) indicated that employee turnover has a high impact on the efficiency, productivity and service delivery of the department (Table 6).

Table 6: Perceived Impact of Employee Turnover on Departmental Efficiency, Productivity and Service Delivery

\begin{tabular}{|c|c|c|}
\hline Impact & Frequency & Percentage of respondents (\%) \\
\hline High & 49 & 81.7 \\
\hline Low & 11 & 18.3 \\
\hline Total & 60 & 100.0 \\
\hline
\end{tabular}

\section{Discussion and Conclusion}

Local government departments in Limpopo Province, as well as work organizations everywhere in the country, have to compete for talent. They have find ways to manage employee retention proactively to ensure that they have the necessary human resource in place to provide services to citizens in the region. However, local government departments in Limpopo Province are losing human capital that the province could ill afford.

Although the present study is retrospective in nature, the department under investigation continue to experience staffing problems. This is evident from the fact that the department had 638 vacant posts in 2010/ 2011. The department could find itself in a vicious cycle of trying to address vacancies through frequently filling many positions, which could increase pressure on existing staff and thus negatively affect the overall success of the organization. If the department does not develop strategies for addressing specific drivers of employee turnover then it may be faced with pervasive skill shortages to fill positions in the future.

Dysfunctional employee turnover is not a significant issue in situations where turnover costs are tolerable. It would appear that employee turnover is problematic in the department targeted in the present study. The findings of the study show that the overall turnover rate is far too high and that it has a severe impact on efficiency, productivity and service. The replacement costs, in particular recruitment costs, for employees in all categories are very high. If the overall turnover rate remains high or increases in the future, then employee turnover will continue to impact on the performance of the department. The department's customers will also continue to regard the department in a negative light. 
It is recommended that the department should use internal and external benchmarking to track its turnover rates over time and to plan strategically to address the problem. In addition, supervisors (lower manager) should be empowered to measure and monitor turnover in their respective units/departments. They should be major players in collecting statistics on turnover because they form a link between management and workers. Moreover, they are responsible for implementing policies at grass root level. A human recourse information system (HRIS) could be used to gather turnover data on a regular basis (Nel, et al., 2011). Turnover targets should be set for the organization and for each individual unit in the organization. A written set of guidelines should be provided to supervisors outlining reasons for turnover, possible control mechanisms, and their role in counselling and offering assistance to subordinates. Supervisors should be trained to implement these steps and they should be held accountable for implementing the steps.

The turnover rates for younger employees, female employees and lower management and operative employees are high compared to the turnover rate of their counterparts. These findings support previous research on age, gender and job category related turnover rates cited in the literature review. Previous research findings showed that younger employees (Generation Y, born between 1961 and 1979) value unexpected rewards for work accomplishments, opportunities to learn new things, praise, recognition, and to spend time with their supervisors (Nel, et.al., 2011). The department should cater for the needs of its younger employees in order to retain them. This could be accomplished by providing them with learning opportunities, supportive supervision, positive feedback and rewards for their accomplishments.

The high turnover rate for female employees is of particular concern. It is recommended that this issue should be investigated further to identify their specific needs and the reasons why they leave the department. Strategies could then be developed to decrease their turnover to an acceptable level. For example, more generous maternity leave and familyfriendly policies, training workshops such as workshops on avoiding sexual harassment or prejudice, equitable compensation schemes and career development opportunities if it is discovers that these issues have to be addressed.

The specific causes of the relatively high turnover rates in the lower management and operative levels in the department should also be investigated further. Focus group interviews could be conducted to determine the causes of turnover in these job categories as recommended by Allen (2008). Interventions can then be implemented to address the problem.

A key external turnover driver identified by respondents is 'better job offers elsewhere'. This confirms the view of Radebe (2009) that government departments have to compete for human resource capacity with organizations in more affluent metropolitan areas in other provinces. The causes for involuntary turnover in the department are deaths, dismissals and retirements. Although 'job related turnover drivers' do not impact on voluntary turnover in the department, evidence suggest that three hygiene factors ('poor compensation', 'poor working conditions' and 'a lack of promotion opportunities') and two motivators ('poor interpersonal relationships' and 'autocratic supervisor management styles') have to be addressed to meet the needs and expectations of employees and to reduce job dissatisfaction and increase the motivation of employees in the department.

Grissom, et al. (2012) and Ito (2003) found that the only way in which organizations can control better job offers by other organizations is to offer competitive compensation packages (pay and benefits). Moreover, the provision of rewards for contribution and performance are strongly related to perceptions of organizational support which in turn are related to turnover intentions (Rhoades \& Eisenberger, 2002). It would be difficult to recommend changes to the department's compensation policy. The human resource manager described human resource policies in the department as 'rigid'. Changes to public sector pay policies cannot be affected unilaterally by individual government departments. The department will have to engage in discussions with central government to address this important issue.

The department will have to make use of strategies to enhance employee engagement and decrease dissatisfaction, for example, by providing positive feedback and recognition for outstanding and value-adding contributions as recommended by Allen (2008). Employees in the department should continuously be reminded of their motivation toward public service to shift their focus from pay to their intrinsic job motivation (Bertelli, 2007).

Supervisors could demonstrate a caring and supportive management style by addressing working condition issues. The improvement of physical working conditions (such as provision of extraordinary equipment and appliances) and psychological working conditions (such as flexible working hours, awards, staff functions and time off), autonomy and job redesign are also recommended to reward job performance and contributions. Supervisors who want to make use of these tactics should obtain top management support, communicate their plans clearly to their subordinates to ensure that they understand why and how they will be rewarded and to ensure that they buy into the ideas, and they should implement their plans fairly and consistently. Supervisors should budget for and address working conditions by inspecting the physical working conditions in their respective departments and by discussing with their subordinates how 
to enhance the quality of the work environment. They should also address issues of work overload and work underload, set realistic work and production targets, and negotiate psychological contracts with their subordinates to ensure that mutual expectations are met in future. The human resource department should coach supervisors in the formulations of psychological contracts (Nel, et al., 2011).

Other ways to create realistic job expectations is to focus attention on staffing and induction practices in the department. The department should provide prospective job applicants with realistic job information. Only applicants who meet minimum job requirement should be considered to fill vacancies (Nel, et.al., 2011). Supervisors should be included in selection panels and should provide input into selection decisions. In addition, the department could review its induction process to ensure that it is effective and efficient. The human resource department should coach supervisors to ensure that they are competent and motivated to manage induction in their units/departments.

Participants in the present study complained that lower level employees remained in the same positions for a long period of time and there is very limited scope for promotion in the department. Job rotation is recommended to vary their experiences. Top management should also support career advancement by encouraging promotion from within and the development of employees' skills. Supervisors should take the value-adding contributions of subordinates into account during performance appraisals. The human resource department should train and monitor supervisors to increase the quality of their performance evaluations and to ensure that they give constructive, developmental feedback to subordinates. This will help employees to focus their career planning and to receive fair promotions as a reward for their contributions. Supervisors should also hold regular focus group meetings with their subordinates to discuss their career development (as recommended by Kim, 2012). Training and development opportunities such as formal training and development programs, workshops, informal sharing groups and mentoring could be provided to prepare employees for promotion.

Perceptions of support and care can also be enhanced by adopting more people orientated leadership styles that would help to lower the effect of poor interpersonal relationships and autocratic supervisor management styles on job satisfaction and turnover. The human resource department should assist supervisors to identify their leadership styles and train them to develop more productive styles as well as their interpersonal skills. Supervisors should learn how to be supportive and how to encourage subordinates to feel free to voice their concerns and assist in decision-making and problem-solving to increase their involvement and engagement. Supervisors should also be open to criticism. They should hold regular focus group meetings with their subordinates to discuss supervisory relationships (recommended by Kim, 2012) and interpersonal issues. They should not only communicate policies and instructions from management to workers and and but should also be employee advocates (Nel, et al., 2011).

It is recommended that the causes of involuntary turnover (deaths, dismissals and retirements) in the department could be managed by redesign jobs or processes to lower the transactions costs associated with involuntary turnover as suggested by Meier and Hicklin (2008).

In line with research findings obtained by Walters (1996), an annual attitude survey is recommended to determine if there are changes in the job satisfaction and job dissatisfaction of employees in the department over time. In addition, this will provide evidence of the effectiveness of retention practices. Furthermore, more in-depth research in needed to find out which specific elements of compensation, working conditions and promotion opportunities cause job dissatisfaction and which components of interpersonal relationships and supervisor management styles cause low job satisfaction. Another fruitful avenue for future research on employee turnover in Limpopo Province would be to compare the findings of the study to studies conducted in other local government departments in the region and nationally.

\section{References}

Abbasi, S. M. \& Hollman, K. W. (2000). Turnover: The real bottom line. Public Personnel Management, 29 (5), 333-342.

Allen, D. G. (2006). Do organizational socialization tactics influence newcomer embeddedness and turnover? Journal of Management, $32,237-25$

Allen, D.G. (2008). Retaining talent: A guide to analysing and managing employee turnover. USA: SHRM Foundation.

Allen, D. G., Shore, L. M. \& Griffeth, R. W. (2003). The role of perceived organizational support and supportive human resource practices in the turnover process. Journal of Management, 29 (1), 99-118.

Azfar, O. \& Danninger, S. (2001). Profit-sharing, employment stability, and wage growth. Industrial and Labor Relations Review, 54 (3): 619-630.

Batt, A., Colvin , J .S. \& Keefe, J. (2002). Employee voice, human resource practices, and quit rates: Evidence from the telecommunications industry. Industrial and Labor Relations Review, 55 (4): 573-94.

Bertelli, A.M. (2007). Determinants of bureaucratic turnover intentions: Evidence from the Department of the Treasury. Journal of Public Administration Research, 17 (2): 235-258. 
Blakemore, A. E., Low, S. A. \& Ormiston, M. B. (1987). Employment bonuses and labor turnover. Journal of Labor Economics, 5 (4): 124-135.

Breaugh, J.A. \& Starke, M. (2000). Research on employee recruitment: So many studies, so many remaining questions. Journal of Management, 26, 405-434.

Bright, L. (2008). Does public service motivation really make a difference on the job satisfaction and turnover intentions of public employees? The American Review of Public Administration, 38, 149-166.

Champion, M. (1991). Meaning and measurement in turnover: Comparison of alternative measures and recommendations for research. Journal of Applied Psychology, 76: 199-212.

Chen, L. (2008). Job satisfaction among information system (IS) personnel. Computers in Human Behavior, 24: 105-118.

Choi, S. L., Musibau, A. A., Khalil, M. N. \& Ebi, S. S. (2012). The approaches to increase employees' loyalty: A review on employees' turnover models. Australian Journal of Basic \& Applied Science, 6 (10): 282-291.

CIPD. (2004). Employee turnover and retention. London: CIPD.

CIPD. (2011). Overview of CIPS surveys: A barometer of HR trends and prospect 2011. [Online] Available: http://www.cipd.co.uk/NR/rdonlyres/315E45C9-B864-4F51-B8D51F39F0738DBE/O/Overviewofsurveysandbarometer20115418.pdf

Cotton, J. L. \& Tuttle, J. M. (1986). Employee turnover: A meta-analysis and review of implications for research. Academy of Management Review, 11: 55-70.

Eisenberger, R., Armeli, S., Rexwinkel, B., Lynch, P. D. \& Rhodes, L. (2001). Reciprocation of perceived organizational support. Journal of Applied Psychology, 86 (1), 42-51.

Evans, M. (2005). On the job. Modern healthcare, 35 (14), 14-15.

Griffith, R. W. \& Horn, P. W. (2001). Retaining valued employees. Thousand Oaks, CA: Sage.

Griffith, R. W., Hom, P. W. \& Gaertner, S. (2000). A meta-analysis of antecedents and correlates of employee turnover: update, moderator tests, and research implications for the next millennium. Journal of Management, 26 (3), 463-488.

Grissom, J. A., Nicholson-Crotty, J. \& Keiser, L. (2012). Does my boss's gender matter? Explaining job satisfaction and employee turnover in the public sector. Journal of Public Administration Research \& Theory, 22 (4): 649-673.

Grobler, P., Wärnich, S., Carrell, M. R., Elbert, N. F. \& Hatfield, R. D. (2006). Human resource management in South Africa. (3rd Ed). London: Thomson.

Guthrie, J. P. (2001). High-involvement work practices, turnover, and productivity: Evidence from New Zealand. Academy of Management Journal, 44 (1), 180-190.

Haines, V. Y., Jalette, P. \& Larose, K. (2010). The influence of human resource management practices on employee voluntary turnover rates in the Canadian non-governmental sector. Industrial and Labor Relations Review, 63 (2): 228-246.

Herzberg, F. (1968). One more time. How do you motivate employees? Harvard Business Review, 46 (1): 53-62.

Herzberg, F., Mausner, B. \& Snyderman, B. B. (1959). The Motivation of Works. (2nd Ed). New York: John Wiley and Sons.

Hom, P.W., Griffith, R.W. \& Sellaro, C. L. (1984). The validity of Mobley's (1977) model of employee turnover. Organizational Behavior and Human Performance, 34 (2): 141-74.

Ikwukanann, I. U. (2009). Correctional officer turnover: Of Maslow's needs hierarchy and Herzberg's motivation theory. Public Personnel Management, 38 (2): 69-82).

Ingraham, P. W., Selden, S. C. \& Moynihan, D. P. (2000). People and performance: Challenges for the future public service-the report from the Wye River Conference. Public Administration Review, 60:54-60.

Ito, J. K. (2003). Career mobility and branding in the Civil Service: An empirical study. Public Personnel Management, 32 (1):1-21.

Kabungaidze, T., Mahlatshana, N. \& Ngirande, H. (2013). The impact of job satisfaction and some demographic variables on employee turnover intentions. International Journal of Business Administration, 4 (1); 53-65.

Kammeyer-Mueller, J.D. \& Wanberg, C.R. (2003). Unwrapping the organizational entry process: Disentangling multiple antecedents and their pathways to adjustment. Journal of Applied Psychology, 88: 779-794.

Kasimati, M. (2011). Job satisfaction and turnover under the effect of person-organization fit in Albanian public organizations. Journal for East European Management Studies. 16 (4): 315-337.

Kellough, J. E. \& Haoran, L. (1993). The paradox of merit pay in the public sector: Persistence of a problematic procedure. Review of Public Personnel Administration, 13 (2):45-64.

Kim, S. (2012). The impact of human resource management on state government IT employee turnover intentions. Public Personnel Management, 41 (2): 257-279.

Lacey, L. M. (2003). Called into question: What nurses want. Nursing Management, 34 (2), 15-16.

Liu, D., Mitchell, T. R., Lee, T. W., Holtom, B. C. \& Hinkin, T. R. (2012). When employees are out of step with co-workers: How job satisfaction trajectory and dispersion influence individual - and unit-level voluntary turnover. Academy of Management Journal, 55 (6): 1360-1380.

London, M. \& Larsen, H.H. (1999). Relationships between feedback and self-development. Group and Organization Management, 24 (1), 5-27.

Long, C. S., Ajagbe, M.A., Nor, K. M. \& Suleiman, E. S. (2012). The approaches to increase employees' loyalty: A review on employees' turnover models. Australian Journal of Basic and Applied Sciences, 6 (10): 282-291.

Lynch, J. \& Tuckey, M. (2008). The police turnover problem: Fact or fiction. International Journal of Police Strategies and Management, 31(1): 6-18. 
Masri, M. (2009). Job satisfaction and turnover intention among the skilled personnel in TRIplc BERHAD. (Master), University Utara Malaysia.

Meier, K. J. \& Hicklin, A. (2008). Employee turnover and organizational performance: Testing hypothesis from classic public administration. Journal of Public Administration Research, 18 (4): 573-590.

Miceli, M. P. \& Mulvey, P. E. (2000). Consequences of satisfaction with pay system: Two Field studies. Industrial Relations, $39: 62-87$.

Moynihan, D. P. \& Landuyt, N. (2008). Explaining turnover intention in state government: Examining the roles of gender, life cycle, and loyalty. Review of Public Personnel Administration, 28:120-35.

Nel, P. S., Erasmus, B. J. \& Swanepoel, B. J. (2001). Human resources management. Cape Town: Oxford University Press.

Nel, P. S., Van Dyk, P. S., Haasbroek, G .D., Schultz, H. B., Sono, T. \& Werner, A. (2011). Human resources management. (8 ${ }^{\text {th }}$ Ed). Southern Africa: Oxford University Press.

Pillay, S (2011). Employee retention: A multiple case study of South African national government departments. (Master), Durban University of Technology.

Porter, L. W. \& Steers, R. M. (1973). Organizational, work, and personal factors in turnover in employee turnover and absenteeism. Psychological Bulletin, 80 (2): 151-176.

Poulin, J. E. (1994). Job task and organizational predicators of social worker job satisfaction change: a panel study. Administration in Social Work, 18(1), 21-39.

Powell, D. (2009). What is wrong with local government? The Magazine of Local Government, October.

Radebe, S. (2009). A task that's achievable. [online] Available: http://free.financialmail.co.za/report09/trade09/btrade.htm

Rainey, H. G. (2003). Understanding and managing public organizations. San Francisco, CA: Jossey-Bass.

Republic of South Africa. (2001). Introduction to performance management for local government in South Africa. Pretoria.

Rhoades, L. \& Eisenberger, R. (2002). Perceived organizational support: A review of the literature. Journal of Applied Psychology, 87(4): 698-714.

Seymour, E. \& Buscherhof, R. J. (1991). Sources and consequences of satisfaction and dissatisfaction in nursing: Findings from a national sample. International Nursing Studies, 28, 109-124.

Shahzad, K., Hayat, K., Abbas, M. \& Bashir, S. (2011). Antecedents of turnover and absenteeism: Evidence from public sector institutions of Pakistan. Interdisciplinary Journal of Contemporary Research in Business, 2 (9): 108-120.

Shaw, J. D., Cupta, N. \& Delery, J. E. (2005). Alternative conceptualizations of the relationship between voluntary turnover and organizational performance. Academy of Management Journal, 84: 50-68.

Sherman, A. W. \& Bohlander, G. W. (1992). Managing human resources. Cincinnati: South-Western Publishing Co.

Sing, D. (2012). Human resource challenges confronting the senior management service of the South African public service. Public Personnel Management, 41 (2): 379-388.

Singh, P. \& Loncar, N. (2010). Pay satisfaction, job satisfaction and turnover intent. Industrial Relations, 65(3): 470-490.

Spector, Paul. (1997). Job satisfaction: Application, assessment, causes and consequences. Thousand Oaks, CA: Sage.

Steel, R. P., Griffith, R. W. \& Hom, P. W. (2002). Practical retention policy for the practical manager. Academy of Management Executive, 16 (2), 149-162.

Stone, R. J. (2008.) Human resource management. (6 $6^{\text {th }}$ Ed). Australia: John Wiley \& Sons.

Sturman, M.C., Trevor, C.O., Boudreau, J.W. \& Gerhart, B. (2003). Is it worth it to win the talent war? Evaluating the utility of performance-based pay. Personnel Psychology, 56, 997-1035.

Sulaiman O. A. \& Ogunsina, S. O. (2011). Influence of supervisory behaviour and job stress on job satisfaction and turnover intention of police personnel in Ekiti State. Journal of Management and Strategy, 2 (3): 13-20.

Tariq, M., Ramzan, M. \& Raiz, A. (2013). The impact of employee turnover on the efficiency of the organization. Interdisciplinary Journal of Contemporary Research in Business, 4 (9):700-711.

Vandenberg, R. J., Richardson, H. A. \& Eastman, L. J. (1999). The impact of high involvement work processes on organizational effectiveness: A second-order latent variable approach. Group and Organization Management, 24(3), 300-339.

Van der Merwe, R. \& Miller, S. (1988). Measuring absence and labour turnover: A practical guide to recording and control. Johannesburg: Lexicon.

Waldman, J. D., Kelly, F., Arora, S. \& Smith, H. L. (2004). The shocking cost of turnover in health care. Health Care Management Review, 29 (1): 2-7.

Walsh, K. \& Tayor, M. S. (2007). Developing in-house careers and retaining management talent what hospitality professionals want from their jobs. Cornell Hospitality Quarterly, 48 (2), 163-182.

Walters, M. (1996). Employee attitudes and opinion surveys. Exeter: Short Run Press.

Wang, Y., Yang, C. \& Wang, K. (2012). Comparing public and private employees job satisfaction and turnover. Public Personnel Management 41 (3): 557-573.

Wright, B. E. \& Kim, S. (2004). Participation's influence on job satisfaction. Review of Public Personnel Administration, 24:18-40.

Yücel, I. (2012). Examining the relationships among job satisfaction, organizational commitment, and turnover intention: An empirical study. International Journal of Business and Management, 7 (20): 41-58. 
